\title{
Equalising the Levels of the Development of the Regions in the Socialist System with the Polish People's Republic as an Example
}

\author{
Edyta Czop
}

\begin{abstract}
After the end of World War II, the Polish authorities had to face post-war reconstruction, integrate the country's economic development within new borders, but also solve problems inherited from the Second Polish Republic: leveling civilization differences between individual regions. These issues were reflected in the plans to modernize the country, promoted by the communists. These plans contained elements of the pre-war modernization concept, but these visions were fundamentally different. The need for industrialization of backward areas proclaimed by the communist authorities was associated with political and social goals. The elimination of regional differences through balanced economic development was combined with the expansion of the working class and the elimination or marginalization of layers considered "capitalist". Additional elements, in fact playing a very large role, were the adoption of the Soviet model of modernization, which was associated with greater or lesser subordination of Moscow's goals and fulfillment of economic tasks resulting from belonging to the CMEA. The problem of sustainable development of the country was particularly strongly emphasized to half of 1.50 . While the country managed to integrate within the new borders, the investment policy did not reduce regional disparities. The location of new industrial plants led to disharmony in the development of Poland. The problem was also not solved in the following years. The reason was: failure of a centrally controlled economy, dominance of obsolete technologies, cyclical breakdowns in the economy, leading to socio-political crises.
\end{abstract}

Keywords: Sustainable development, modernization, centrally controlled economy, investment policy, socialism

After the $2^{\text {nd }}$ World War, Polish authorities had to deal with the after-war reconstruction, integrate the economic development of the country within its new borders and solve the problems which had already existed in the Second Polish Republic, i.e. offsetting the civilization differences between the regions.

What turned out to be of particular importance was the issue of equalising the levels of the socio-economic development in the respective regions of Poland. The seriousness of the problem had already been known in the 30 s of the $20^{\text {th }}$ century, which was reflected in the ideas for the modernization of the country. However, their implementation was interrupted by the outbreak of the $2^{\text {nd }}$ World War.

When working on the leconomic programs, communists (who took over the power in 1944) referred to the pre-war modernization programs, but they used the soviet model and the communist doctrine as the foundation. Offsetting the differences between the respective regions through the sustainable economic development was understood as walking away from the free market mechanisms, the expansion of the working class and the liquidation or marginalization of the "capitalist" strata. Therefore, the modernization was going to happen through the reconstruction of the economic and socio-political 
system according to the soviet model.

The accepted idea of the dictated and manually controlled modernization of the country and the improvement of the living conditions of its citizens (within the frames of the central distribution in the economy), which ignored or selected certain rules of the free market, did not bring the expected results despite the implementation of new economic plans, investment "booms" and the extensive industrialization.

After 1945, the Polish People's Republic was reborn as an agricultural and industrial country with the old-fashioned agricultural structure, weak internal market and different levels of the economic development in the respective regions of Poland. The border changes were drastic - Poland lost $20 \%$ of its territory. What was to compensate the border shift and war losses was the post-German area which turned out to be devastated to a greater extent than the territory of central Poland (in the German territory $73 \%$ of the industry was destroyed, whereas on the territory of the

former lands - 62\%). Moreover, new territory was weakened due to the depredation policy of the Russian army (Zawistowski, 2010, pp. 184-185).

The economic situation was also influenced by the loss of population. Poland lost about $20 \%$ of its population, whereas Yugoslavia - 11.7\%, the Soviet Union - 8.9\%, Greece $6.8 \%$, Austria $-5.7 \%$, Germany $-5 \%$. Relatively, the loss of population in Poland was the biggest among the countries taking part in the $2^{\text {nd }}$ World War. We also need to remember about the disabled and people sick of tuberculosis and other communicable diseases. Such situation had an impact on the work productivity in agriculture and industry (Zawistowski, 2010, p. 185).

All those aspects need to be taken into consideration when discussing the modernization of the after-war Poland and the activities undertaken to offset the differences in the living conditions of people living in different parts of Poland.

New authorities adopted the concept of the modernization based on the soviet model which, to a great extent, had a mimetic character. It assumed the top down transformation of all aspects of the economic, social and political life according to the soviet model. It was of total character and its final effect was going to be the construction of the socialist system. On one hand, it included the concepts of economic development, sustainability of the regional development and the improvement of living conditions to the level achieved in Western Europe, on the other hand, it aimed at building a new socio-political and economic system. The ideas which gave ground to the soviet model of modernization were introduced, e.g. the gradual reduction of the private sector (with the ultimate goal to eradicate it - the nationalization of the industry 1946, "the battle over the trade" 1947) and social sector, the introduction of the foundations for the centrally controlled economy, which was associated with the reduction of the market mechanisms, and last but not least - the politicization of economic entities (Musial 2013, pp. 165-166).

The creation of the after-war program of the economic reconstruction of Poland caused the conceptual disputes among the most important political forces between 1945 and 1946. They agreed that the reconstruction should be involve the restoration and integration of the country in its new borders, the modernization of its output and greater share in the international exchange. They also shared an opinion that overpopulation in the countryside and unemployment in cities had to be eliminated and living conditions 
improved. The differences concerned the methods and the pace of the transformations as well as the role of the industry in the economy of the country.

In 1946, slaskie, lodzkie and wroclawskie voivodships were the most industrialized, which resulted from the actual, high, level of industrialization before the war and relatively low level of destruction during the war. The regions in the north-east and south-east of Poland were the exact opposite, which partly resulted from the underdevelopment before the war and partly from the destructions during the war, e.g., in Elblag or Bialystok (Jezierski, Leszczynska 2002, pp. 427-428). Communists wanted to mitigate these disparities by means of the radical economic reconstruction. The Polish Workers' Party opted for the industrialization based on the soviet model and fought against the agricultural concepts promoted by the Polish People's Party. The supporters of the Polish People's Party believed in the agricultural and industrial structure of the country and the deglomeration of the industry. They were of the opinion that the uniform distribution of industry in the country would lead to full employment of local workforce and the economic activation of the neglected areas.

The industrialization was also supported by some Polish Socialist Party activists. However, they opted for a harmonious economic development and a consistent improvement of the living conditions of citizens. With the changing political conditions in the country as well as abroad, their standpoint shifted towards the acceleration of the development of the means of production (Kalinski 2005, pp. 34-35).

The compromise between those various standpoints laid foundation for the three-year Plan of Reconstructing the Economy for the period of 1947 and 1949. According to the act, the main tasks were: the reconstruction of the socio-economic structure, the integration of the post-German lands with the rest of the country and the use of the sea access in the economic development (Journal of Laws from 1947, no 53, item 285). The results of the implementation of the plan were positive, which had an impact on the shape of the new six-year plan. The living situation of citizens improved, employment increased, the post-German lands were integrated with the rest of the country, the transport improved, especially the railway. Taking into consideration the industrialization of the respective regions in 1949, slaskie, lodzkie and wroclawskie voivodships still dominated, which mainly resulted from the ideas behind the three-year plan which, at least theoretically, did not assume any major new investments. In reality, the first steps towards the extensive industrialization were made in the last year of the implementation of the plan.

The continuation of the industrialization process according to the soviet model established the foundation for the six-year plan. At the Convention of the Polish United Workers' Party and the Polish Socialist Party, Boleslaw Bierut, the leader of Polish communists, announced further economic development of Poland through "the development of the nationalized and planned economy based on better technical and organizational foundations and new, not common in the former times, rate of increase in manufacturing forces and the increase in production". He further expressed his thought to the Sejm in 1952 sharing an opinion that a quick industrialization of the country "is the only reliable way to eliminate the underdevelopment of our economy, the condition for the consistent increase in our strength, our prosperity, our culture" (as cited in Wojnicki 2018, p. 117). The ideas included, e.g., increasing the level of "the economic 
and cultural activity in the underdeveloped eastern and central parts of the country and in some insufficiently developed counties in the western and northern voivodships by means of the adequate policy of the distribution of manufacturing forces" (Journal of Laws from 1950, no 37, item 344). It was a reference to the work of the Central Office for Spatial Planning on the plan of the spatial development of the country in the 40s. Partial deglomeration of industrial and urban centres, better transport solutions, the decrease in the overpopulation of the countryside, the regionalization of the production and the uniform urbanization based on the industry were also expected. (Kalinski 1995, p. 51).

The creators of the Six-Year Plan wanted to modernize the entire economy through the development of the industry which produced capital goods. They took the soviet fiveyear plan as an example. They wanted to further develop the infrastructure and to coordinate its respective branches. The communication disparities were going to be mitigated and the transport structures modernized. Industrialization was going to involve the liquidation of the elements of the capitalist economy, the collectivization of agriculture, stronger economic relation with the Soviet Union and other countries of the eastern bloc and the improvement of the standard of living. By doing so, communists wanted to set up the foundation for the socialist system. The name of the plan itself confirmed it: "Six-Year Plan of Economic Development and Building the Foundations of Socialism in Poland for the period of 1950-1955" (Kalinski, Landau 2003, pp. 236237).

The economic dogmas and the international situation resulted in the expansion of the capital intensive branches of the industry and its militarization, which had an important impact on the structure of the industry. The secret plan of the development of heavy and machine industry was implemented and it involved arming and the creation of petrol and natural resources base (Kalinski 2012, pp.49-50).

The Six-Year Plan resulted in the establishment of the economic foundations which were based on the traditional heavy and chemical industry. Nowa Huta (metallurgic conglomerate), Huta Aluminium in Skawina, power plant "Jaworzno" and chemical conglomerate in Oswiecim became the symbols of the intensive industrialization. The created structure of the industry fulfilled the natural conditions and the social needs of the country only to a limited extent. It was because of the fact that it was created as the result of the doctrinal assumptions, the use of the soviet solutions and the international situation (the war in Korea). The economic development deviated from the World tendencies and strategies adopted by highly developed countries (Kalinski 2012, p. 50). Contrary to the assumptions, the disparities in the development of the country were not mitigated. The location of new factories, which was very often politically (Nowa Huta) or strategically conditioned, made the existing disharmony even greater. New factories were very often located in the most industrialized voivodships where the existing infrastructure and qualified staff was used. That's why, small cities gave way to big agglomerations (Kalinski 2012, pp. 50-51; Kalinski, Landau 2003, pp. 247-248).

The role of Zaglebie Dabrowskie, Warsaw, Upper Silesia, Krakow was strengthened and the industrial situation improved in lubelskie, rzeszowskie and krakowskie voivodships. Warszawskie, kieleckie (with a few exceptions), bydgoskie and zielonogorskie were neglected. Not many new investments were initiated in the regions with little or no 
industry. What also hit small cities was the liquidation of small-scale production and crafts (Kalinski 2005, p.47; Kalinski 1995, p. 61; Zawistowski 2010, p. 192).

Intensive industrialization was accompanied by the attempt at making social and technical changes in agriculture. It involved collectivization, which turned out to be a failure. Despite emphasising the need for the uniform development of production cooperatives in the entire Poland, the disparities existed even in this field. Villages in the central and eastern voivodships did not want to accept the collectivization and villages in the western and northern voivodships, i.e. in the post-German areas, got its greatest share. (Kalinski, Landau 2003, pp. 248-251).

The strategy of the intensive economic development of the country resulted in the growing infrastructural needs. Unfortunately, the plans for the development of transport were systematically limited and the available resources were spent on the industry. This resulted, e.g., in the underdevelopment of railway electrification. The transit routes, mainly of military importance, leading from the east to the west, were preferred. In the case of the road transport, the main routes were modernized and improved. The construction of new roads concentrated in the investment regions and in the south-east area of Poland which, until then, had been neglected (Kalinski 2003, pp. 251-253).

The industrialization, based on the communist doctrine and realized in the unfavourable international situation, was characterised by autarky and militarization. The concentration of investments in the selected branches of industry had a negative impact on the production of consumer goods and housing. Unemployment was not fully eliminated either. The disparities in the economic development of the regions were linked to local unemployment. This resulted in the lack of the market balance, leading to the stagnation in the standard of living of citizens. The disparities between the development of industry and agriculture were becoming greater and the underdevelopment of the latter caused the provision problems. Cutting investments in transport and low spendings on housing did not allow to rebuild cities after the war. The economic and social infrastructure was also underdeveloped. The scale of the disparities in the middle of the 50s had an impact on the socio-economic crises in the future (Kalinski 1995, pp. 77-78).

In 1956, Wladyslaw Gomulka returned to the authority in the country and this initiated the change in the attitude towards the economic development and the economic policy of communists. After walking away from the intensive industrialization (due to political reasons), its new phase started at the end of the 50s. It was based on the doctrinal elements, the direction of the economic policy set out for the countries of the eastern bloc by Nikita Chruszczow, the leader of the Soviet Russia, and the need of making use of the discovered raw materials. The underdevelopment of Poland (in comparison to many other European countries) was related to the scale of production and the used technologies and this wasn't without any significance. Another reason for coming back to the intensive industrialization was the need to employ people from the after-war population boom (Zawistowski 2010, pp. 197-198).

In the first half of the $60 \mathrm{~s}$, the policy of the spatial economic development led to the establishment of new industrial areas. It partially resulted from the discovery of sulphur, copper, lignite and cocking coal deposits. New factories were also located in the areas which, until then, had been economically neglected. This, to some extent, mitigated the disparities in the development of the country. Simultaneously, new branch offices of the 
factories, located in the main regions of the industry concentration, which had to deal with the problem of workforce, were set up. They were located in the areas with insufficient industry and, with time, they were going to become independent. Deglomeration of the industry mitigated the disparities in the development of the country, however it did not eliminate them. The industrialization and urbanization processes covered warszawskie, lubelskie and kieleckie voivodships which, until then, had been neglected. At the same time, the plan to make use of the closed facilities on the Western and Northern Lands was, to some extent, implemented (Zawistowski 2010, pp. 197-201; Kalinski 1995, pp. 112-113; Kalinski 2012, p. 52).

One of the positive aspects of offsetting the civilization differences in the country, especially in the case of the neglected areas, was further modernization and the construction of communication networks. The end of the 50s brought the expansion of the road networks in the eastern and southern voivodships as well as in the areas of new investments (Kalinski 1995, p. 94). However, the number of initiated investments was still not big enough. The second phase of industrialization, despite activation of new branches of the industry, had a limited impact on the modernization of the country and its socio-economic structure. The disparities in the economic development were not eliminated either. What is more, the problem of the technological gap, which resulted from the underdevelopment of the Polish industry, was becoming more serious. It stemmed from the insufficient scientific, technological and civilization progress of the Polish People's Republic. Slow pace of the modernization also concerned agriculture, foreign trade, services and transport. The centralized way of the management of the economy did not favour the changes either (Kalinski 1995, pp. 294-295).

Poland entered the $70 \mathrm{~s}$ with the anachronistic agricultural structure, ineffective agricultural cooperatives and State Agricultural Farms. Low level of the economic development, the lack of industrial specialization, the inability to keep up with the World economic trends had a negative impact on the industrial situation in the country. Low level of industrialization and irrational agricultural structure placed Poland among economically underdeveloped countries with poor standards of living. The level of the national revenue was comparable with the level in Italy, Spain, Bulgaria, Romania and Hungary (Kalinski 1995, pp. 296-297).

The new leadership, with Edward Gierek in charge, wanted to counteract the bad economic condition of the country. They prepared the strategy for the "dynamic and harmonious" development, which was never defined and permanently changing. It assumed comprehensive actions in the machine, electronics, iron and steel, chemical and light industry. In agriculture, it aimed at the development of the production in bigger individual households and, simultaneously, at making the role of the state and cooperative sector more crucial. It seemed that the new leadership noticed the problem of the uneven spatial development of the country and the need for environmental protection (Kalinski, 2005, p. 73).

In the first half of the 70s, the biggest (in the history of the after-war Poland) industrialization took place. The need for the development of big cities and urban and industrial agglomerations was emphasized. In the context of the spatial development, the investment decisions intensified the phenomenon of the excessive concentration of industry in big agglomerations (Zawistowski 2010, 203-204; Kalinski 2012, p. 58). 
Such policy contradicted the announcements made by Edward Gierek when he was taking over the power in the country. He announced the changes in the managing system and a new action plan. The changes would involve the decentralization of management and the introduction of certain market elements - prescriptive indicators were to be replaced by parametric indicators (profits) which were going to be used in the evaluation of enterprises. The committee established for the purpose of preparing the reforms, called for the concentration of factories, i.e. the establishment of "big economic organizations". The reorganization of industry and the establishment of big economic organizations was initiated in 1972, which eliminated field industry (apart from Warsaw and katowickie voivodship) which served the local market. Big economic organizations were established as the replacement of former industrial unities (in 1975, they generated 67\% of production) (Jezierski, Leszczynska 2002, 503-504).

In accordance with the decision made by the government on $4^{\text {th }}$ August 1972, field factories were controlled by the trade ministries (55 factories) or the Ministry of the Internal Trade and Purchasing Centres (17). The plan was to leave only those factories of the field industry which were necessary in services and local market. Simultaneously, their possibilities to cooperate with key enterprises were limited. In May 1972, the Planning Committee commanded that the majority of the enterprises of the field industry should be incorporated in the structures of unities and trade centres (Budzinski M. http://kolegia.sgh.waw.pl/pl/KES/czasopisma/kwartalnik/Documents/Utworzenie $\% 20$ Wielkich $\% 20$ Organizacji $\% 20$ Gospodarczych $\% 20 \% \mathrm{E} 2 \% 80 \% 93 \% 20 \mathrm{za} \% \mathrm{C} 5 \% 82 \mathrm{O} \% \mathrm{C} 5 \% \mathrm{~B}$ Cenia\%20reformy.pdf (30th March 2019, 168-169).

The strategy, adopted at the beginning of the $70 \mathrm{~s}$, revealed its negative consequences already in the middle of the decade: overinvesting, imitative modernization and the incompetent introduction of purchased technologies from which other countries had already been walking away. The mid 70s exposed the negative structure of Polish economy which could not be fixed with any temporary solutions (Musial 2013, 205).

The investment surge of the 70 s was the last one on such a big scale. At the beginning of the $80 \mathrm{~s}$, due to the growing crisis, the initiated investments were "frozen" and no new investments introduced. By the end of the decade, the focus was on finishing the initiatives of the previous decade, the fight against the mounting crisis and the improvement of standards of living (Zawistowski 2010, 205-206).

When we compare the distribution of the industry in 1950 and 1973, the dominance of five voivodships is clearly visible: katowickie, warszawskie, wroclawskie, krakowskie and lodzkie, where $56 \%$ of industrial production was located. Therefore, the main industrial centres, which had their origin in the $19^{\text {th }}$ century during the industrial revolution, still dominated. The positive aspect of the economic and socio-political changes was the mitigation of the disparities between the respective regions of the country, especially in comparison to the period of the Second Polish Republic. However, it was, to a great extent, the result of the changes of the Polish territory and its adjustment to the economic and infrastructure development rather than the planned activities of the communist authorities. New factories were located with the consideration of the location of raw materials deposits, infrastructure and qualified staff. However, it is difficult to create the infrastructure and adjust it to the civilization needs within a few years. The progressing concentration of the industry had a negative impact of the environment. On 
the other hand, however, the industrialized after-war areas underwent the socioeconomic transformation less drastically after 1989 (Jezierski, Leszczynska 2002, pp. 507508).

Although it was possible to economically integrate the country in its new borders, the investment policy did not mitigate the regional disparities. The location of new industrial factories led to the disharmony in the development of Poland. The reasons for that were: failure of the centrally controlled economy, the dominance of old-fashioned technologies, regular economic downturns which led to socio-political crises.

\section{References}

Journal of Laws from 1947, no 53, item 285

Journal of Laws from 1950, no 37, item 344

Budzinski M, Utworzenie Wielkich Organizacji Gospodarczych - zalozenia reformy przemyslu PRL lat 70.,http://kolegia.sgh.waw.pl/pl/KES/czasopisma/kwartalnik/Documents/Utworzenie $\% 20 \mathrm{Wiel}$ kich $\% 20$ Organizacji $\% 20$ Gospodarczych $\% 20 \% \mathrm{E} 2 \% 80 \% 93 \% 20 \mathrm{za} \% \mathrm{C} 5 \% 82 \mathrm{o} \% \mathrm{C} 5 \%$ BCenia $\% 20$ ref ormy.pdf (30.03.2019)

Jezierski A., Leszczynska C., Historia gospodarcza Polski, Warszawa 2002

Kalinski J., Gospodarka Polski w latach 1944-1989. Przemiany strukturalne, Warszawa 1995

Kalinski J., Historia gospodarcza Polski Ludowej, Bialystok 2005 Kalinski J., Gospodarka w PRL, Warszawa 2012

Kalinski J., Landau Z., Gospodarka Polski w XX wieku, Warszawa 2003

Musial W., Modernizacja Polski. Polityki rzadowe w latach 1918-2004, Torun 2013

Wojnicki J., Kwestie gospodarcze w referatach przywodcow Polski Ludowej (in:) Gospodarka PRL. Wybrane zagadnienia, ed. W. Gieszczynski, Olsztyn 2018

Zawistowski A., Polska Ludowa. Wzrost podporzadkowany doktrynie politycznej (in:) Polskie osiagniecia gospodarcze, ed. J. Kalinski, Warszawa 2010 